\title{
PD46 - Serum level of S 100 proteins in patients with asthma
}

\author{
Theodora Gioka', Theocharis Konstantinidis ${ }^{1}$, Christina Tsigalou', Eleni Hatziioannou', Georgia Kampouromiti ${ }^{1}$, \\ Dimitrios Cassimos $^{2^{*}}$ \\ From 3rd Pediatric Allergy and Asthma Meeting (PAAM) \\ Athens, Greece. 17-19 October 2013
}

\begin{abstract}
Aim
Asthma is a chronic disease of the lower respiratory tract that is characterized by inflammation and bronchial obstruction. The pathophysiology of the disease is related to constriction of the bronchial smooth muscle, something that is influenced by calcium homeostasis. Important role in calcium homeostasis, play various binding proteins, which belongs to the family of proteins S100 (S100). The purpose of this study was to measure S100 protein in a group of children with bronchial asthma (BA) in comparison with age-sex matched control group.
\end{abstract}

\section{Materials and methods}

10 patients (mean age $8 \pm 4.6,60^{\prime \prime}$ and $4 \%$ ) and 10 age-sex matched controls (mean age $7.4 \pm 3.1,40^{\circ}$ and 6 \%) were included in our study; Patients with acute infection were excluded from this study in order to avoid blases that could lead to misinterpretation. Serum S100 protein was determined by electrochemeluminescent method and level of protein $\geq 0,105 \mu \mathrm{g} / \mathrm{l}$ was considered positive.

\section{Results}

All asthmatic patients (100\%) had abnormal serum levels of S100. Asthmatic patients presented a significantly higher level of S100 in comparison to control subjects $(0.31 \mu \mathrm{g} / \mathrm{l}$ vs $0.065 \mu \mathrm{g} / \mathrm{l}, \mathrm{p}<0.05)$.

\section{Conclusions}

Our results in this study group demonstrated that S 100 elevated in asthmatic children, in a statistical significant manner. The role of $\mathrm{S} 100$ needs to be further

${ }^{2}$ Pediatric Department, University General Hospital of Alexandroupolis, Alexandroupolis, Greece

Full list of author information is available at the end of the article investigated, imposing a possible new therapeutic target in the pathophysiology of asthma.

\section{Authors' details}

${ }^{1}$ Immunology Department of Microbiology Laboratory, University General Hospital of Alexandroupolis, Alexandroupolis, Greece. ${ }^{2}$ Pediatric Department, University General Hospital of Alexandroupolis, Alexandroupolis, Greece.

Published: 28 February 2014

\section{doi:10.1186/2045-7022-4-S1-P46}

Cite this article as: Gioka et al:: PD46 - Serum level of S 100 proteins in patients with asthma. Clinical and Translational Allergy 2014 4(Suppl 1):P46.
Submit your next manuscript to BioMed Central and take full advantage of:

- Convenient online submission

- Thorough peer review

- No space constraints or color figure charges

- Immediate publication on acceptance

- Inclusion in PubMed, CAS, Scopus and Google Scholar

- Research which is freely available for redistribution
() Biomed Central
C Biomed Central

(c) 2014 Gioka et al; licensee BioMed Central Ltd. This is an Open Access article distributed under the terms of the Creative Commons Attribution License (http://creativecommons.org/licenses/by/2.0), which permits unrestricted use, distribution, and reproduction in any medium, provided the original work is properly cited. The Creative Commons Public Domain Dedication waiver (http://creativecommons.org/publicdomain/zero/1.0/) applies to the data made available in this article, unless otherwise stated. 